\title{
Testing the Relationship between Female Labour Force Participation and Fertility in Nigeria
}

\author{
Oyeyemi Omodadepo Adebiyi \\ Department of Economics, Accounting and Finance, College of Management Sciences, \\ Bells University of Technology, Ota, Nigeria \\ realyemmymeji@gmail.com \\ Temitayo Alice Onifade \\ Department of Business Administration, College of Management Sciences, \\ Bells University of Technology, Ota, Nigeria \\ onifadeng@yahoo.com
}

Doi:10.5901/mjss.2014.v5n27p1322

\section{Abstract}

The study analysed the relationship existing between female labour force participation and fertility in Nigeria. We used Ordinary least Squares to estimated annual data obtained from the World Development Indicator from 1998-2011. It was found that a positive but insignificant relationship exists between female labour force participation and fertility in the country. Also, Literacy rate and contraceptive prevalence influences fertility positively while GDP per capita has a negative influence on fertility. Furthermore, microeconomic data from obtained from Nigeria Demographic and Health Survey was used to investigate the relationship using simple correlation coefficient. We found a negative relationship between female labour force participation and fertility as well as a negative relationship between fertility and contraceptive usage but a positive relationship between literacy rate and fertility. The study concluded that female labour force participation has little impact on fertility in the country; it is possible to be a mother and a worker or a student at the same time in Nigeria.

Keywords: Fertility; Female Labour Force Participation; literacy rate

\section{Introduction}

In Nigeria, there has been a noticeable increase in the participation of women in economic market than it has ever been before. Contrarily, fertility is declining as evidenced by figures 1 and 2. Scholars have tried to identify the reason for this relationship. The trend could be explained by changes in the work preferences of women and the optimal number of children. Women motivation to participate in the labour force has improved in recent years; girls have better education and some government policies also favour this.

\section{Figure 1:}

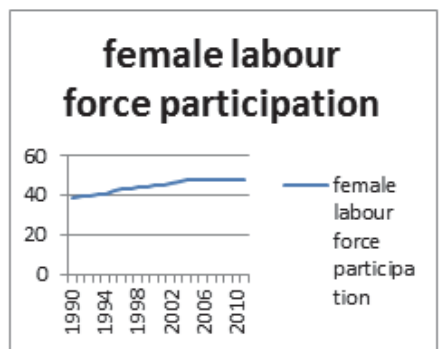

Figure 2:

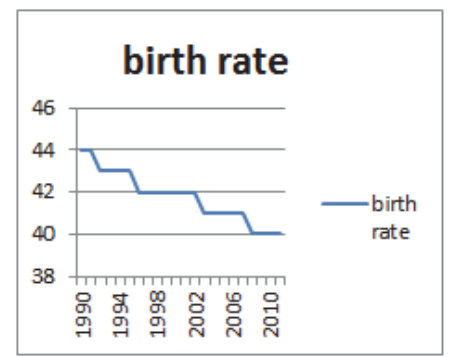

Source: World Development Indicator

Also, in recent times, the optimal number of children a woman is willing to have reduced since the ability of a child to 
survival has improved through improved medical care; high infant mortality could make a woman be willing to have as many children as possible, since the probability of one to survive is low. Likewise, increased schooling years for girls reduces fecundity period, thereby leaving them with the option of having fewer children than they would have had if they did not go to school. Furthermore, the development and wide use of contraceptive methods can help in explaining the trend. Contraceptive technology enhances households to schedule birth till when they want and stop having children whenever they have attained the desired number of children they want. This enables the woman to stay employed and accumulate human capital (through trainings and experience on the job) but schedule birth till when it is convenient and would not hinder their human capital development.

Interestingly, empirical findings are inconclusive on the relationship. While some studies found out that higher wages should increase the opportunity costs of childbearing and reduce fertility (Becker, 1993 and Oppenheimer, 1994); this theoretical phenomenon represents the basis of the substitution effect, others in contrast, have found a positive impact of female employment on the transition rate to higher order births i.e. income effect (Rocha and Fruster, 2005 and Kravdal, 2002). Another relationship that is more applicable to the African continent was proposed by Younger (2006); some female employment can be bounded together with child rearing therefore, female employment may have little or no effect on fertility decisions. Younger (2006) further proposed that the communal living of Africans encourages a woman to have as many children as possible while working or schooling since there can always be a family member or friend to help nurse the child.

Hence, this study seeks to investigate empirically the existing relationship between female labour force participation. Most existing studies on this are microeconomic framework while studies on Nigeria are rare.

Literature is reviewed in section two and data and method of analysis is discussed in section three. Section four discusses the result and the conclusion was discussed in section five.

\section{Literature Review}

Most fertility theories are explained by demographic transmission theory which attempts to capture attempts the process of change from a situation of high mortality and high fertility to a situation of low mortality and low fertility. This study is an aspect of demographic transmission theory because it attempts to explain the decline in the birth rate as affected by female labour force participation.

\subsection{Empirical Review}

Beguy (2009) investigates the impact of female employment on fertility in two urban contexts in sub-Saharan Africa: Dakar (Senegal) and Lomé (Togo). In Dakar, he used 397 household samples collected by French Institute of Research for Development (IRD -EquipeJeremi) and the University of Dakar (Institut Fondamentald'Afrique Noire - IFAN), while 1060 samples were analysed In Lomé, the data came from a retrospective survey - Survey on Migrations and Urban Integration in Lomé. He used Cox model and regression to analyse the data collected. He found that in Dakar neither female employment nor human capital has a significant effect on the likelihood of giving birth. Contrarily, Education and Employment hinders fertility significantly.

Kim et al.(2009) analysed the relationship between fertility and poverty for Indonesia. The used difference-inDifference and Probit method to analyse household data from Indonesia Family and Life Survey. He illustrated the sensitivity of the effect of fertility on household consumption with respect to the equivalence scale in a unitary household framework. Using the propensity score matching method, the analysis suggested that a new-born child decreases household consumption per person by 20 per cent within four years. When the estimates of equivalence scales implied by the Indonesian sample were applied, the effect of a child on household consumption was still negative, but the magnitudes are in the range of 20 to 65 per cent of that found with the per-capita expenditure. He concluded that given that household preference for consumption of private goods such as children's education is negatively associated with fertility, the test for household bargaining supports the model of the unitary household as a valid assumption for examining the relationship between fertility and household consumption.

Bhalla and Kaur (2011) explored the determinant of labour force participation of females in India. They used Tobit Model to estimate household data. They found that Income growth and female education has a positive impact on female labour force participation while female discrimination has a negative relationship with female labour force participation. 


\subsection{The Nigerian Experience}

Osili and Long (2004) analysed the relationship between female schooling and fertility. They used Difference-in Difference, Difference-in-Difference-in- Difference and Instrumental Variable techniques to analyse data from the 1999 Nigerian Demographic Health Survey (NDHS) for 8199 women. They found that the expansion in female education had a significant positive impact on education and a negative significant impact on fertility decisions.

Babalola and Akor (2013) examined the factors affecting labour force participation of married women within the working age (18-60) in Adamawa state. The Probit model was used to analyse observation for 120 women. It was found that education has positive effect on female labour force participation while husband's employment and household size has a negative effect on female labour force participation.

Okpala (1989) examined the relationship between labour force participation and fertility in an urban centre (Lagos, Nigeria). Primary data were collected from three categories of women (civil servants, self-employed and house wives). Both descriptive statistics and ordinary least square were used to test the data. When chi-squared was used, he found that the fertility level of civil servants is lower than that of businesswomen and housewives. Also, not much difference exists between the fertility level of businesswomen and that of housewives. When OLS was used, he found a significant negative relationship between fertility and female labour force participation among civil servants. Among self-employed women, a negative relationship still exists but it is insignificant.

Nwakeze (2006) examined the determinants of demand for children in Anambra state, Nigeria. Logistic Regression Technique was used to analyse cross-sectional data from 1787 households in a survey conducted in the state in year 2000. Factors identified as strong predictors of demand for children are wife's level of participation in decision-making, occupation, place of residence and husband's education. Wife's education is a weak predictor of demand for children. This supports the assumption that female education is a necessary but not sufficient condition to guarantee fertility decline.

There has been few existing studies that investigated the relationship between fertility and female labour force participation even at a microeconomic level in Nigeria. This study intends to fill this gap in literature.

\section{Data and Method of Analysis}

The study obtained annual data on crude birth rate (FET), Female labour force Participation (FLP), Gross Domestic product per capital (GDPP), Literacy rate (LR) and Contraceptive Prevalence for women (PC) from the World development indicator of the World Bank for the periods 1998-2011. We started by analysing the trend and pattern of the variables. Also, the time series property of the data was tested, and then we proceed to OLS estimate. Following Okpala (1989), fertility is specified thus:

$F E T=\propto_{0}+\propto_{1} F L P+\propto_{2} \log G D P P+\propto_{3} L R+\propto_{4} P C+\epsilon$

Furthermore, we obtained household data from Nigeria Demographic and Health Survey for 2003 and 2008. We used simple correlation coefficient to test for the relationship among the variables.

\section{Analysis and Result}

\subsection{Trend Analysis}

Figure 3: Trend of FLP, FET and LR

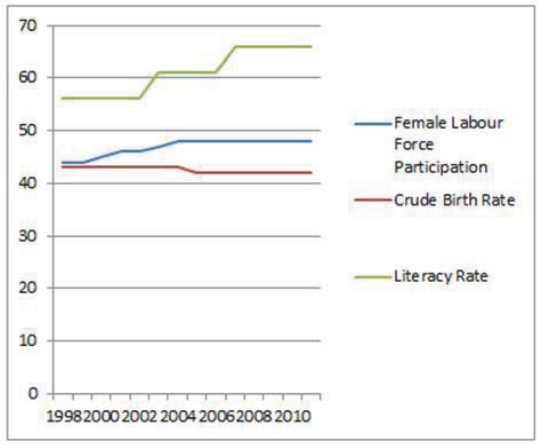


Figure 4: Trend of GDPP

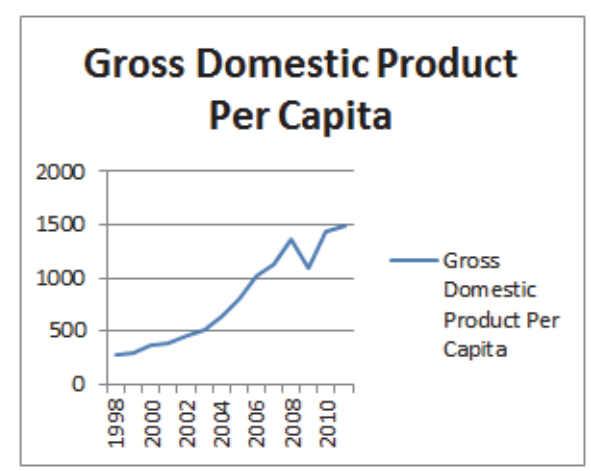

Source: World Development Indicators

Female labour force participation increased in year 2000, crude birth rate and literacy rate remained the same. In 2003, female labour force participation as well as literacy rate increased while crude birth rate is still the same. Gross domestic product per capita was slightly increasing prior 2003 but started increasing rapidly from the same year. It is possible that the effect of policies and programmes put in place by democratic governance was just being effective in the country by the year 2003. Female labour force participation increased in 2004, but has since then been stagnant. Crude birth rate was stagnant all through the period of consideration except for a slight decrease it had in 2005. Gross domestic product per capita increased all through the considered period bud dropped in 2009; this may be attributed to a shock in global economy which in turn affected the country's financial system. Except for gross domestic product per capita, the pattern of other variables have slight changes over the years, we can infer that most programme and policies put in place by the government impart slightly on this various indicators. Unit Root Test

In order to test for the time series property of the data, we applied both Augmented Dickey Fuller and Philip Perron to test for the unit root. The result is summarized in the table I below. The result revealed that all the variables are not stationary at levels. All variables except FLP are stationary at first difference while FLP is stationary at second difference.

Table I: Philip Perron and Augmented Dickey Fuller Test

\begin{tabular}{|c|c|c|c|c|c|c|c|}
\hline \multicolumn{4}{|c|}{ Philip Perron } & \multicolumn{4}{c|}{ Augmented Dickey Fuller } \\
\hline Variable & Status & Adjusted T Statistics & Probability & Variable & Status & T Statistics & Probability \\
\hline FET & $\mathrm{I}(1)$ & $3.4707^{\star *}$ & 0.0293 & FET & $\mathrm{I}(1)$ & $3.4646^{\star \star}$ & 0.0296 \\
\hline FLP & $\mathrm{I}(2)$ & $9.3166^{\star}$ & 0.0000 & FLP & $\mathrm{I}(2)$ & $6.7365^{\star \star}$ & 0.0004 \\
\hline GDPP & $\mathrm{I}(1)$ & $5.9529^{\star}$ & 0.0006 & GDPP & $\mathrm{I}(1)$ & $5.9287^{\star}$ & 0.0006 \\
\hline LR & $\mathrm{I}(1)$ & $6.0222^{\star}$ & 0.0005 & LR & $\mathrm{I}(1)$ & $3.8729^{\star \star}$ & 0.0151 \\
\hline CP & $\mathrm{I}(1)$ & $3.1622^{\star \star *}$ & 0.0486 & CP & $\mathrm{I}(1)$ & $3.1622^{\star \star}$ & 0.0486 \\
\hline
\end{tabular}

$\star(\star \star)\left[{ }^{\star \star \star}\right]$ indicates significance at $1 \%(5 \%)[10 \%]$

Due to the nature of the unit root we could not proceed to cointegration test. This implies that there is no long run relationship among the variables specified in this work. We then proceed to analyse Ordinary Least Squares and the result is reported below. 


\subsection{Ordinary Least Squares}

Table II: OLS Result

\begin{tabular}{|c|c|c|c|}
\hline Variable & Coefficient & t-Statistic & Probability \\
\hline C & -0.3469 & -0.2705 & 0.7947 \\
FLP & 0.2841 & 1.7602 & 0.1218 \\
GDPP & -0.3758 & -0.6076 & 0.5626 \\
LR & 0.0023 & 0.05805 & 0.9553 \\
PC & 0.0831 & 0.6582 & 0.5314 \\
\hline \multicolumn{2}{|c|}{ FET -Dependent Variable } \\
\hline
\end{tabular}

$\left.{ }^{*}\right)$ indicate significance at (1\%).

The explanatory power (R-square) for the OLS estimate is 34\%; the implication of this is that only less than $35 \%$ of the variables specified (FLP, GDPP,LR and CP) can explain the variation in fertility in Nigeria. Durbin-Watson is 2.49 indicating that there is no serial autocorrelation among the variables. Female labour force participation is positively signed and statistically not significant this implies a positive relationship between female labour force participation and fertility. GDPP is negatively signed and statistically not significant implying that the higher the income the lower the fertility rate in the country. Literacy rate is positively signed but statistically insignificant; the implication of this is that literacy increases fertility. Contraceptive prevalence is also positively signed but statistically not significant; by implication, literacy rate increases fertility in Nigeria.

\subsection{Household Data Analysis}

Due to the nature of the OLS result as well as the trend analysis, we further seek to know the behaviour of microeconomic data on the variables of interest. We proceed to using household data from Nigeria Demographic and Health Survey for 2003 and 2008. A t-test and a simple correlation coefficient were conducted on FET (children ever born), FLP (percentage of women working for cash in the last twelve months), LR (women literacy rate) and PC (contraceptive usage among women). The result is displayed in table III below. T-statistics reveals that all the variables are statistically significant at $1 \%$. The correlation coefficient shows that there exists an inverse relationship between fertility and female labour force participation and contraceptive prevalence. Literacy rate has a positive relationship with fertility.

Table III: Result of t-test and correlation coefficient

\begin{tabular}{|l|c|c|c|c|}
\hline & FET & FLP & LR & PC \\
\hline t-statistics & $44.3^{\star}$ & $8.738^{\star}$ & $10.589^{\star}$ & $5.772^{\star \star}$ \\
\hline Correlation coefficient & 1 & -0.98 & 0.96 & -0.92 \\
\hline
\end{tabular}

$*(* *)$ indicates significance at $1 \%(5 \%)$

\section{Conclusion}

The study examined the relationship between female labour force participation and fertility in Nigeria. From the OLS result, we observed that female labour force participation leads to increase in fertility; this may be in agreement with Younger (2006) who assumed that in developing countries, some work may be bounded with child rearing. In addition, communal living in Africa make it easy to raise children; family members and friends are always ready to assist in raising new-borns. Therefore, labour force participation of the woman has little or no effect on fertility. Income level is inversely related to fertility. Literacy rate influences fertility positively; also we will follow Younger (2006)- it is possible to be a mother and a student at the same time. Contraceptive prevalence among women increases fertility; the reason for this is not clear, we suggest a further investigation to this for future researchers. When microeconomic data was used, correlation coefficient revealed a negative relationship between fertility and female labour force participation, a negative relationship between female labour force participation and contraceptive usage but a positive relationship between female labour force participation and literacy rate. The direction of the relationship when microeconomic data was used contradicts when macroeconomic data was used, except for literacy rate that is positively related to female labour force participation in both. 


\section{References}

Babalola, J. and Akor, M (2013). An Empirical Analysis of Labour Force Participation of Married Women in Adamawa State, Nigeria. Journal of Emerging Trends in Economics and Management Sciences,4(1):1-7

Becker G. S. (1993). A Treatise on the Family. Enlarged edition. Cambridge (Massachusetts). Harvard University Press.

Beguy, D. (2009). The impact of female employment on fertility in Dakar (Senegal) and Lomé. Demographic Research, volume 20.

Bhalla, S and Kaur, R. (2011). Labour Force Participation of Women in India: Some facts, some queries. Asia Research Centre Working Paper, 40

Kim J., Engelhardt H., Prskawetz A. and Aassve A.(2009). Does fertility decrease household consumption? An Analysis of Poverty Dynamics and Fertility in Indonesia. Demographic Research, Volume 20, Article 26

Kravdal, O. (2002). Education and Fertility in Sub-Saharan Africa: Individual and Community Effects. Demography, Vol. 39, No. 2, pp. 233-250.

Nwakeze, N. (2006). The Demand for Children in Anambra State of Nigeria: A Logit Analysis. African Population Studies, Vol. 22 no2

National Bureau of Statistics (2003) "Nigeria Demographic and Health Survey"

National Bureau of Statistics (2008) "Nigeria Demographic and Health Survey"

Okpala, A.O. (1989). Female Employment and Family Size among Urban Nigerian Women. The Journal of Developing Areas, Vol. 23, No. 3, pp. 439-456

Osili, U. and Long, B. (2004). Does Female Schooling Reduce Fertility? The Case of Universal Primary Education in Nigeria. Journal of Development Economics, 87(2008) 57-75

Oppenheimer V. K. (1994). Women's rising employment and the future of the family in industrial societies. Population and Development Review, 20(2), 293-342;

Rocha, J and Fruster, L (2005). Why are Fertility Rates and Female Employment Ratios Positively Correlated across O.E.C.D. Countries?

Younger, S. (2006) Labor Market Activities and Fertility. African Economic Research Consortium. 